今月の症例

\title{
ベタメタゾン点鼻液長期使用にて, 医原性Cushing症候群を来たした1例
}

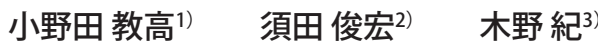

72 歳, 男性. 軽微な打撲で上肢に皮下出血を来たし, 赤ら顔, 満月様顔貌を認め, Cushing症候群が疑われ た. 3 年前より，ベタメタゾン含有製剤を点鼻で継続使用していたことから，外因性ステロイドが原因であるこ とが判明した. 被疑薬剤を中止, ヒドロコルチゾンの補充漸減療法にて症状は軽快した. 副腎皮質ホルモン製剤 は，投与経路にかかわらず, 内因性の視床下部一下垂体一副腎系を抑制し得ることを認識する必要がある.

[日内会誌 $107 ： 2513 \sim 2517 ， 2018]$

ポイント・・局所投与による副腎皮質ステロイド製剤であっても,CRH(corticotropin-releasing hormone)ACTH (adrenocorticotropic hormone)ーコルチジール系を抑制し，医原性Cushing症候群 を来たし得る.

・全ての副腎不全のなかで，外因性のグルココルチコイドによるものが最も多い.

・投与薬剂を中止する場合は，本来必要な生理的ホルモン量を推察し，慎重な補充漸減療法 が必要である.

Key words ベタメタゾン点鼻薬，医原性Cushing症候群，薬剤性副腎不全

\section{はじめに}

副腎皮質ステロイド製剤は, 膠原病や呼吸器 疾患をはじめ, 多くの診療科において広く使用 される薬剤である．治療には薬理学的量が必要 であることから, 高頻度に副作用も発生する。 そのなかでも, 感染症や骨粗鬆症, 消化管疾患, 糖尿病, 精神神経障害, 動脈硬化病変の進行等 は, 放置すると重篤化する可能性があり, 常に モニターする必要がある。一方で，外因性に投 与された副腎皮質ホルモンが, 内因性のCRH (corticotropin-releasing hormone)-ACTH (adre- nocorticotropic hormone)-コルチゾール系を抑 制することによる, 続発性の副腎不全は見落と されていることが多い.

今回, 力価の高いベタメタゾンの点鼻経路で の使用により, 副腎不全, 医原性Cushing症候群 を来たした症例を経験したので報告する。

\section{症例}

患者：72歳, 男性.

主訴: 上肢皮下出血, 満月様顔貌.

現病歴：海産業を営んでおり, 暗い冷凍庫内 


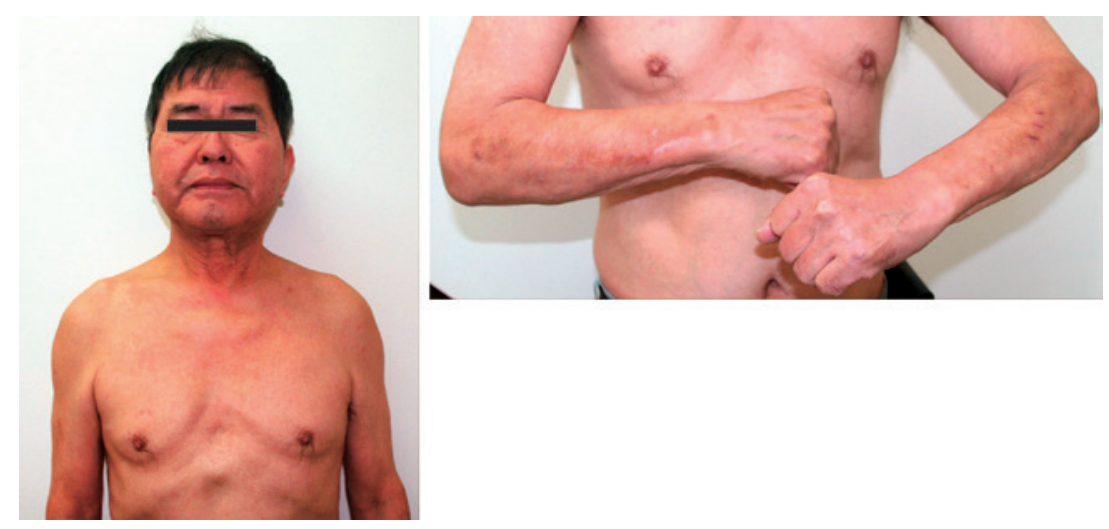

図 1 初診時の身体所見

満月様顔貌及び前腕に多数の皮下出血斑を認める. 皮膚の菲薄化あり.

で仕事をすることが多かった，5～6 年前より， 前腕を強く打撲すると, 同部位に皮下出血がみ られたが, 通常 2 週間程度で消退していた. 3 年 前に嗅覚の低下を自覚, 鼻炎の診断で, 近医よ りベタメタゾン点鼻液を処方され, 初めの 1 力 月は両鼻に各 1 回 1 pushを毎日, その後は 1 日お きに使用していた. 特に全身倦㤐感, 食欲不振, 体重減少等は認めなかったが, 最近, 軽微な打 撲でも皮下出血を認めるようになったため, 当 院外来へ紹介受診となった。

既往歴：45歳より 高血圧，68歳 大腸ポ リープ切除.

家族歴：両親・子供 2 人ともに特記すべき事 項なし.

生活歴：喫煙 1日20本（20４0歳），飲酒 焼酎 1 合（20歳～現在).

身体所見：身長 $162.0 \mathrm{~cm}$, 体重 $62.0 \mathrm{~kg}, \mathrm{BMI}$ 23.6. 体温 $36.6^{\circ} \mathrm{C}$. 心 拍 $75 /$ 分, 整. 血圧 145/88 mmHg. 顔面赤ら顔, 満月様顔貌あり. Buffalo humpは認めないが, 背部にわずかに毛 細血管拡張あり。皮膚線条なし。両側上肢に限 局した皮下出血斑あり, 皮膚の菲薄化あり(図1).

内服薬：アムロジピン $5 \mathrm{mg} /$ 日, エチゾラム $0.5 \mathrm{mg} /$ 日, ゾルピデム $5 \mathrm{mg} /$ 日, トコフェロー ル $600 \mathrm{mg} /$ 日, オロパタジン $10 \mathrm{mg} /$ 日, メコバ
ラミン $1,500 \mu \mathrm{g} /$ 日. 血液検査所見 : Hb $12.5 \mathrm{~g} /$ $\mathrm{dl}$, 白血球 $5,200 / \mu \mathrm{l}$ (好中球 $59.5 \%$, 好酸球 $1.4 \%)$, 血 小板 19.7 万 $/ \mu \mathrm{l}$, PT活性 $118.7 \%$, APTT 26.8 秒, BUN $14 \mathrm{mg} / \mathrm{dl}, \quad$ Cr $0.65 \mathrm{mg} / \mathrm{dl}$, AST 20 IU/1, ALT 17 IU/1, Glu (空腹時) 101 mg/ dl, HbA1c 5.6\%, Na 140 mEq/l, K 4.0 mEq/l. ホルモン検査 (AM9時, 空腹時) : ACTH $2.5 \mathrm{pg} /$ $\mathrm{ml}$, コルチゾール $0.5 \mu \mathrm{g} / \mathrm{dl}$, アルドステロン $102 \mathrm{pg} / \mathrm{ml}$, アドレナリン $12 \mathrm{pg} / \mathrm{ml}$, ノルアドレ ナリン $108 \mathrm{pg} / \mathrm{ml}$, レニン活性 $3.2 \mathrm{ng} / \mathrm{ml} /$ 時間.

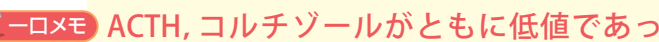
ても，Cushing徴候を来たす病態がある ことを見逃してはいけない. 内服薬以外 にも，局所に投与する薬剤についても詳 細に問診することが重要である.

\section{臨床経過}

体型的に肥満は認めないものの, 特徴的な顔 貌と繰り返す皮下出血から, Cushing症候群を 疑った。しかしながら, 午前の採血でACTH $2.5 \mathrm{pg} / \mathrm{ml}$ (基準值7.2〜 63.3 pg/ml), コルチゾー ルが $0.5 \mu \mathrm{g} / \mathrm{dl}$ （基準值 4.5 21.1 $\mu \mathrm{g} / \mathrm{dl}$ ）と，い ずれも正常範囲を下回っていた。この段階で, 外因性の副腎皮質ステロイド製剤による，医原 


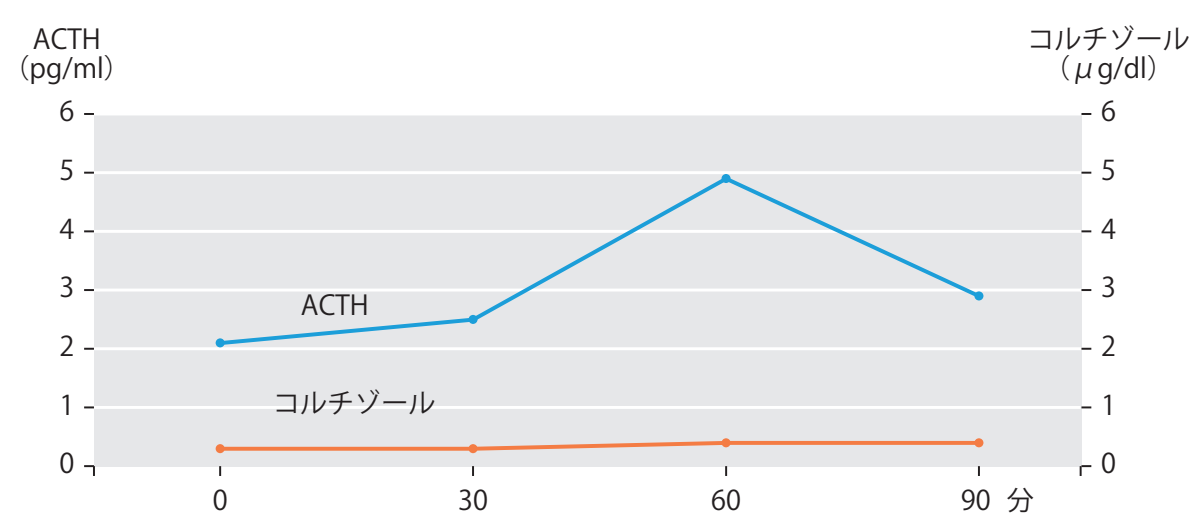

図 $2 \mathrm{CRH}$ 負荷試験による ACTH，コルチゾールの変化

朝 9 時, 30 分間，静脈ルートを留置した条件下で，CRH $(100 \mu \mathrm{g})$ を単回静注した. ACTH

のピークは，前値の 2.3 倍で頂值も低い.コルチゾールはほとんど反応がみられない.

性Cushing症候群を疑ったが, 内服薬に被疑薬は 存在しないため,さらに詳細に聴取したとこ ろ, ベタメタゾン含有製剤を 3 年間継続使用し ていたことが判明した。点鼻薬を前日まで 1 日 おきに継続した条件下で，CRH負荷試験を実施 した（図2). ACTH，コルチゾールともに基礎 值低值，低反応であった。以上より，鼻腔より 体内に吸収されたベタメタゾンによる，視床下 部一下垂体一副腎系の抑制が確認され, 臨床症 状から医原性Cushing症候群と診断した。

ーーロメモ 外因性の副腎皮質ホルモンの投与を受 けている場合，プレドニゾロン換算で 1 日 $7.5 \mathrm{mg}$ 以上， 3 週間以上投与を受けた 場合，内因性副腎機能の抑制が起こり得 るとされている1)。

本薬剤によって嗅覚の低下は改善しておら ず，継続のメリットがないことより中止し，同 時にヒドロコルチゾン内服による，補充漸減療 法を開始した。初期量を $15 \mathrm{mg}$ (朝食後 $10 \mathrm{mg}$,

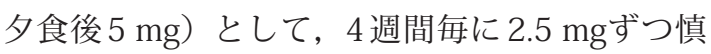
重に減量を行った。減量中の感染やストレス時 の副腎不全対策として，内服増量も指導してい たが, 経過中, 発熱や倦怠感, 食欲低下等の副 腎不全兆候を認めず，半年後に問題なく中止す
ることができた。この時点での血圧は 141/70 mmHg, 空腹時血糖值 $91 \mathrm{mg} / \mathrm{dl}, \mathrm{HbA} 1 \mathrm{c}$ $5.2 \%$ であった。初診 1 年後には, 血圧 145/75 mmHg と著変を認めず, 空腹時採血で, 血糖值 $98 \mathrm{mg} / \mathrm{dl}$, 一方ACTHは $22.3 \mathrm{pg} / \mathrm{ml}$, コル チゾールは $7.7 \mu \mathrm{g} / \mathrm{dl}$ と正常化がみられ, 前腕の 皮下出血も軽快した。

\section{考察}

副腎皮質ステロイドであるべタメタゾンは， ヒドロコルチゾンに比べて抗炎症作用では約 25倍の高力価とされているが, その生物学的半 減期は 36〜 72 時間と極めて長い。今回，医原

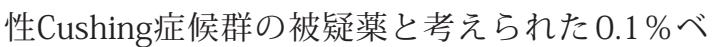
タメタゾン点鼻液は, 1 本 $5 \mathrm{ml}$ 中にベタメタゾ ン $3.8 \mathrm{mg}$ を含有するため, ヒドロコルチゾン換 算で約 $95 \mathrm{mg}$ となる. 実際はこれを約 1〜2力月 に1本消費していた. 1日あたりの量としては決 して多くはないが, 長い半減期と長期使用が CRH-ACTH-コルチゾール系への抑制をかけた ものと考えられた.

ベタメタゾン等の合成ステロイドの代謝の一 部には， $6 \beta$ 位の水酸化が関与するが，その主な 
代謝酵素はCYP3A4である。本例で併用された， アムロジピン, エチゾラム, ゾルピデムの代謝 にも一部CYP3A4 が関わるために, 酵素の競合 阻害によって, さらにステロイド作用が増強さ れた可能性も考えられた。

長期に亘って，副腎皮質ステロイド製剤が治 療上必要な疾患には, 膠原病, 呼吸器疾患をは じめ, 抗炎症作用を期待する数多くの適応症が 存在する.内服や経静脈投与では，しばしば体 重増加や満月様顔貌等のCushing徴候を経験す る一方で, 外用剤や点眼, 点鼻薬等局所に含ま れるステロイドについては, 普段, その全身作 用を意識することはほとんどない。以前から， クロベタゾール, ジフロラゾン, ベタメタゾン 等のステロイド含有皮膚科用剤を, 比較的広範 囲に長期に使用することで, 視床下部-下垂体一 副腎系が抑制されることは知られていた2). ま た, 呼吸器領域で用いる, 硫酸イソプレナリン 配合薬, フルチカゾンやブデソニド等の吸入ス テロイド薬でも報告が増えている3 $。$ 。゙タメタ ゾンは全身に吸収されやすく, 医原性Cushing症 候群を来たしたと考えているが，局所代謝性の フルチカゾン点鼻液でも報告されており，あら ゆる薬剤で発症し得る ${ }^{4)}$.

全ての副腎不全のなかでも, 外因性コルチコ ステロイド使用によるものが最も多い5)。最近 74 文献, 総数 3,753 症例をまとめた, 外因性ス テロイド製剤による副腎不全に関する初めての メタアナリシスが発表された6)。その発生頻度 は，投与経路別に，経口 $48.7 \%$, 吸大 $7.8 \%$, 経皮 $4.7 \%$, 経鼻 $4.2 \%$, 関節内 $52.2 \%$ であっ た。症状の併記のある10のレポートによると, 521 人中 10 人のみが副腎不全の症状を訴えた が，検査によって98人が副腎不全と診断され た.すなわち, 症状のある人のみを対象とする と，88人は見逃されていたことになる．恐ら く, 報告されていない潜在性の副腎皮質機能低 下症が多く存在することを示唆する.
外因性の副腎皮質ホルモンによる医原性 Cushing症候群と診断した場合, その後の対応に も注意を要する7 . 視床下部一下垂体-副腎系が 完全に抑制されている状態では, 生理的に必要 な副腎皮質ホルモンも外因性に依存して抢り， 急激な投与中止やストレス時には, 生命予後に 影響を及ぼす事態を招きかねない。一般にコル チゾールの1日あたりの分泌量は9〜 $11 \mathrm{mg} / \mathrm{m}^{2} /$ 日とされており ${ }^{8)}$, 本症例ではヒドロコルチゾ ン $15 \mathrm{mg}$ から補充漸減療法を行った. 最終的 に確認したコルチゾール值は $7.7 \mu \mathrm{g} / \mathrm{dl}$ と基準值 内ではあったが, 負荷試験による予備能の検索 は実施できなかった. ACTH単独欠損症も完全に は除外しきれておらず，今後も慎重なフォロー アップが必要と考えている.

ーーロ㕵医原性Cushing症候群と診断した場合， 突然外因性のステロイド製剤を中止す ることは危険であり，時に生命を脅かす こともあるため，注意を要する.

\section{最終診断}

\section{医原性Cushing症候群}

\section{おわりに}

外因性のステロイド製剤は，使用量が多く， また，使用期間が長いほど，視床下部一下垂体一 副腎系の抑制の発生頻度は高くなる。投与経路 や原疾患に関係なく, 続発性の副腎不全は発症 し得る.たとえCushing症候群が医原性であって も，感染や骨折リスクを上げてしまうことか ら，投与方法にかかわらず，ステロイド製浏使 用時には，常に注意を払うことが肝要である.

著者のCOI (conflicts of interest) 開示: 本論文発表内容 に関連して特に申告なし 
1) Stewart PM, Newell-Price JDC : Secondary hypoadrenalism. Melmed S, eds, Williams Textbook of Endocrinology, 13th edition, Philadelphia, 2016, 526-528.

2) Hengge UR, et al : Adverse effects of topical glucocorticosteroids. J Am Acad Dermatol 54 : 1-15, 2006.

3) Lipworth BJ : Systemic adverse effects of inhaled corticosteroid therapy : a systematic review and meta-analysis. Arch Intern Med 159: 941-955, 1999.

4）関谷綾子：フルチカゾン点鼻薬とリトナビル併用により医原性クッシング症候群をきたした 1 例. HIV感染症とAIDS の治療 7:47-50, 2016.

5) Arlt W, Allolio B : Adrenal insufficiency. Lancet 361 : 1881-1893, 2003.

6) Broersen LH, et al : Adrenal insufficiency in corticosteroids use : systematic review and meta-analysis. J Clin Endocrinol Metab 100:2171-2180, 2015.

7）柳瀬俊彦，他：副腎クリーゼを含む副腎皮質機能低下症の診断と治療に関する指針. 日本内分泌学会雑誌 91 (Suppl) : 56-57, 2015.

8) Kraan GP, et al : The daily cortisol production reinvestigated in healthy men. The serum and urinary cortisol production rates are not significantly different. J Clin Endocrinol Metab 83 : 1247-1252, 1998. 